Original Article

\title{
VALIDATION OF STABILITY INDICATING ULTRA-FAST LIQUID CHROMATOGRAPHY METHOD FOR SIMULTANEOUS ESTIMATION OF ATENOLOL and NIFEDIPINE IN BOTH BULK AND PHARMACEUTICAL DOSAGE FORMS
}

\author{
ARUNSRIKAR M., R. S. CHANDAN*, ANAND KUMAR TENGLI, VENKATA SAIRAM K. \\ Department of Pharmaceutical Chemistry, JSS College of Pharmacy, JSS Academy of Higher Education and Research, Mysuru 570015, (KA), India \\ Email: rschandan@jssuni.edu.in
}

Received: 22 Jan 2018, Revised and Accepted: 08 Mar 2018

\begin{abstract}
Objective: The study depicts improvement of ensuing validation of a stability indicating technique for the simultaneous estimation of Atenolol and Nifedipine using Ultra-fast liquid chromatographic method (UFLC).

Methods: The analysis is performed on Phenomenex Kinetex $\mathrm{C}_{18},(150 \times 4.6 \mathrm{~mm}, 5 \mu \mathrm{m})$ column using methanol and 0.1\%ortho-phosphoric acids $(75: 25 \mathrm{v} / \mathrm{v})$ as mobile phase with a flow rate of $1.3 \mathrm{ml} / \mathrm{min}$. The eluents were checked with PDA detector at $237 \mathrm{~nm}$.

Results: In this optimized conditions Atenolol and Nifedipine elutes at a retention time of 2.79 and 4.50 min respectively individually the considered optimized condition is having linearity in the range from 10 to $50 \mu \mathrm{g} / \mathrm{ml}$ of Atenolol and $4-20 \mu \mathrm{g} / \mathrm{ml}$ of Nifedipine. The method was validated by following the ICH guidelines and their combination drug yield was exposed to acid and base stress, thermal stress, photolytic stress, hydrolytic stress, and oxidative stress conditions. All samples were studied by the given optimized method. In this Calibration curves were linear over studies ranges with correlation coefficient found between the ranges of 0.99 to 1.00 .
\end{abstract}

Conclusion: The proposed method was found to be accurate, precise, and specific and suitable for determination of both the drugs.

Keywords: Atenolol, ICH guidelines, Nifedipine, Stability indicating studies, UFLC

(C) 2018 The Authors. Published by Innovare Academic Sciences Pvt Ltd. This is an open access article under the CC BY license (http://creativecommons.org/licenses/by/4.0/)

DOI: http://dx.doi.org/10.22159/ijcpr.2018v10i3.27224

\section{INTRODUCTION}

Atenolol, 4-[2-hydroxy-3-[(1-methyl ethyl) amino] propoxy]benzeneacetamide] [1] (fig. 1) is a cardio-selective $\beta_{1}$-adrenergic receptor blocking agent recommended for the treatment of hypertension, angina pectoris, and cardiac arrhythmias. It is a Beta blocker that intrudes with binding to the receptor of epinephrine and different stress hormones and decreases the impacts of these hormones. Beta blockers are especially utilized for the management of cardiovascular arrhythmias, shielding the heart from second attack (myocardial infarction) after a first heart attack and hypertension [2]

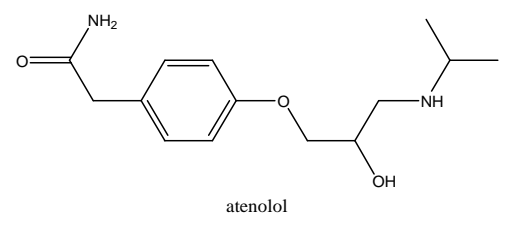

Fig. 1: Chemical structure of atenolol

Nifedipine is dimethyl-,4-dihydro-2,6-dimethyl-4-(2-nitrophenyl) pyridine 3,Sdicarboxylate [3]. (fig. 2) Nifedipine is a calcium channel blocking agent. The principal activity of calcium channel blockers incorporate dilatation of coronary and fringe coronary and peripheral arteries and arterioles, negative in tropic activity, decrease the heart rate, and decelerate the atrioventricular (AV) conduction. It restrains the Trans layer influx of calcium ions into vascular smooth muscle and cardiovascular muscle. Nifedipine restrains calcium ions influx across cell membranes specifically, with a more impact on vascular smooth muscle compared to cardiac muscle cells ${ }^{4}$ Combined use of Atenolol with Nifedipine decreases the properties of cardiac muscles especially in patients with ventricular or conduction abnormalities [5-7].

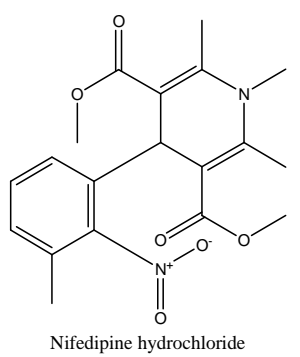

Fig. 2: Chemical structure of nifedipine

The proposed technique was optimized and validated as per International Conference on Harmonization (ICH) guidelines. [8-10]. The aim of the present work is to develop a simple, fast, precise and accurate reversed-phase chromatographic method together with stability indicating studies for the both mix drugs Atenolol and Nifedipine in bulk and its pharmaceutical dosage forms.

\section{MATERIALS AND METHODS}

\section{Chemicals and reagents}

The HPLC grade methanol is acquired from Merck Pvt Ltd, Mumbai. The chemicals utilized are of analytical grade (AR grade) like orthophosphoric acid obtained from Loba Chemie, Mumbai.

\section{Instrumentation}

The SHIMADZU, UFLC with PDA detector and LC solution software was utilized in the current research work. The separation was accomplished using C18 column. The mobile phase contains of $0.1 \%$ orthophosphoric acid in water and methanol $(75: 25 \mathrm{v} / \mathrm{v})$. The mobile phase was filtered before use through membrane filters $(0.45 \mu)$. The upgraded chromatographic conditions were mentioned in given table 1 . 
Table 1: Optimized chromatographic conditions

\begin{tabular}{ll}
\hline Column & $\mathrm{C}_{18}(150 \times 4.6 \mathrm{~mm}, 5 \mu \mathrm{m})$ Phenomenex Kinetex \\
Flow rate & $1.3 \mathrm{ml} / \mathrm{min}$ \\
Run time & $10 \mathrm{~min}$ \\
Wavelength & $238 \mathrm{~nm}$ \\
Injection Volume & $20 \mu \mathrm{L}$ \\
Detector & PDA Detector \\
Elution & Isocratic \\
Mobile Phase & Methanol and $0.1 \%$ ortho-phosphoric acid $(75: 25 \mathrm{v} / \mathrm{v})$ \\
Column oven temperature & $25 \pm 5^{\circ} \mathrm{C}$ \\
\hline
\end{tabular}

\section{Preparation of mobile phase}

The mobile phase is prepared by adding $1 \mathrm{ml}$ of orthophosphoric acid in $1000 \mathrm{ml}$ water (ie; $0.1 \%$ orthophosphoric acid in $1000 \mathrm{ml}$ water) and methanol this mobile phase is ultra-sonicated used for 20 min were used in the ratio of 75:25(v/v).

\section{Preparation of standard solutions}

A standard stock solution of Atenolol and Nifedipine was prepared by dissolving $50 \mathrm{mg}$ Atenolol and $20 \mathrm{mg}$ of Nifedipine drugs in $50 \mathrm{ml}$ of methanol made up to the volume by dissolving completely using the methanol to get the standard stock solutions of concentration $1000 \mu \mathrm{g} / \mathrm{ml}$ for Atenolol and $400 \mu \mathrm{g} / \mathrm{ml}$ Nifedipine.

\section{Preparation of calibration curve}

From the standard stock solutions, different aliquots of Atenolol and Nifedipine were pipetted into series of $10 \mathrm{ml}$ volumetric flask from the above stock preparation $(1000 \mu \mathrm{g} / \mathrm{ml})$. HPLC grade methanol was used for making up the volume. $20 \mu$ l solution was injected to the column and peak areas are measured. The calibration curve was established linear correlations were found between peak scales. Atenolol and Nifedipine concentration are defined my means of regression equation (fig. 3 and fig. 4 respectively). The Beer's law is observed in the concentration scale of $10-50 \mu \mathrm{g}$ of Atenolol and Nifedipine $4-20 \mu \mathrm{g} / \mathrm{ml}$ Estimation of two drugs was done through PDA detector at $238 \mathrm{~nm}$.

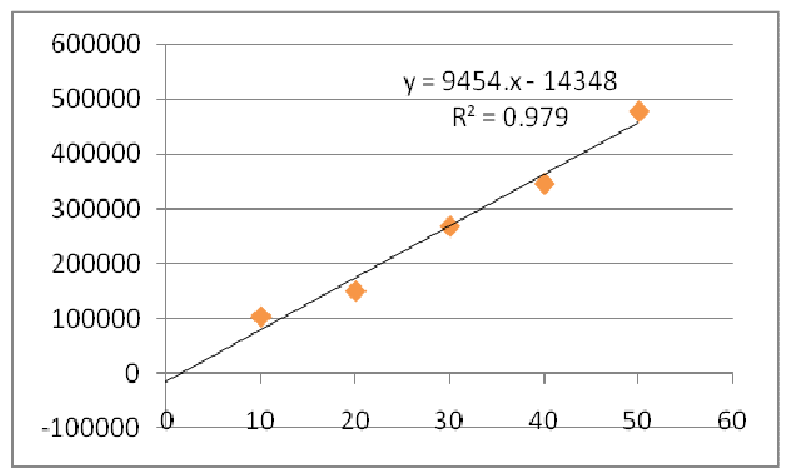

Fig. 3: Linearity graph of atenolol

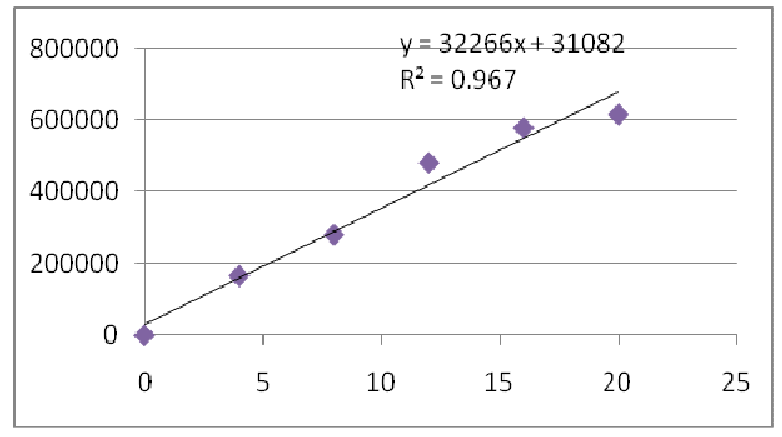

Fig. 4: Linearity graph of nifedipine

\section{Preparation of sample solution of formulation}

Into a dry $50 \mathrm{ml}$ volumetric flask finely grounded and mixed contents of 20 capsules with equivalent weights of $50 \mathrm{mg}$ Atenolol and $20 \mathrm{mg}$ of Nifedipine were taken and ultra-sonicated until the drug dissolved in methanol then made up to the volume. At $238 \mathrm{~nm}$ area of each peak was measured. From the peak area, we determine the amount of each drug, atenolol and Nifedipine respectively present in the pure mixture. Upon further quantitative dilution of this solution with mobile phase, a final concentration of $50 \mathrm{mg} / \mathrm{ml}$ of Atenolol and Nifedipine was obtained.

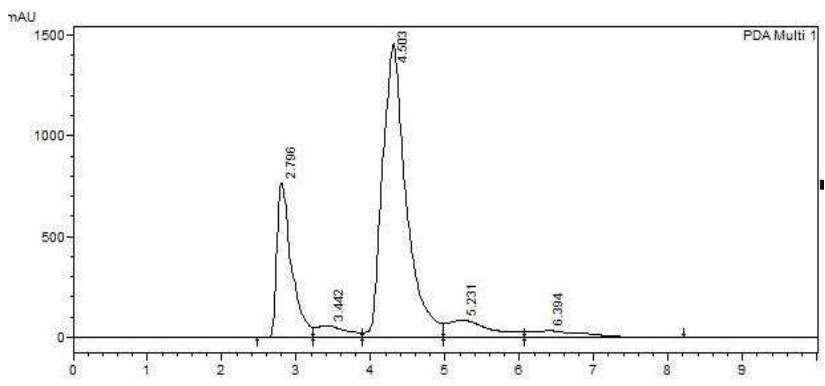

Fig. 5: Standard chromatogram of atenolol and nifedipine

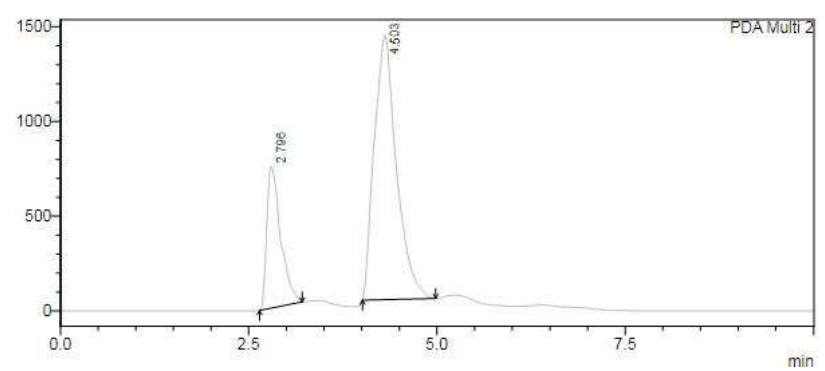

Fig. 6: Sample chromatogram of atenolol and nifedipine

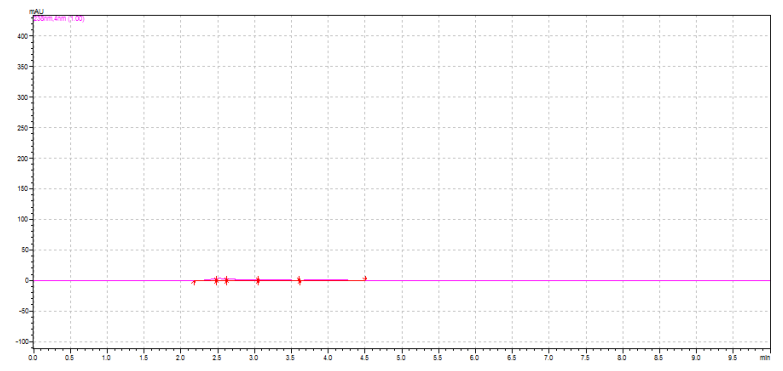

Fig. 7: Chromatogram of blank

\section{RESULTS AND DISCUSSION}

Linearity, precision, accuracy, limit of detection (LOD) and limit of quantification (LOQ), robustness is the parameters to be validated for all samples according to the ICH guidelines using above chromatography conditions. 


\section{Linearity}

Linear calibration curves of both Atenolol and Nifedipine were obtained based on the above chromatographic conditions. The $\mathrm{r}^{2}$ for Atenolol and Nifedipine were found to be 0.979and 0.967 respectively. Between the peaks area of Atenolol and Nifedipinelinear correlations were found and are described by using regression equation. Table 2 specifies the results. For system suitability, Atenolol and Nifedipine and the linearity range were found to be $10-50 \mu \mathrm{g} / \mathrm{ml}$ and $4-20 \mu \mathrm{g} / \mathrm{ml}$ respectively.

\section{Precision}

Repeatability (injection and analysis) and intermediate precision (intra-day and inter-days reproducibility) are the terms to determine the method precision mentioned below in table 3 and 4 .

\section{Accuracy}

According to the test procedure triplicates of samples solutions by spiking with the test solutions of Atenolol and Nifedipine 50\%,
$100 \%$ and $150 \%$. Prepared separately and injected into UFLC system to establish the accuracy of the test method. The results were summarized in below table 5 by calculating the spike levels of the amount of drug added, amount of drug found and average $\%$ recovery for atenolol and Nifedipine $50 \%, 100 \%$ and $150 \%$.

\section{Robustness}

A measure of capacity to stay unaffected by small, but deliberate variations in the final method optimized conditions', called robustness for an analytical procedure as per ICH guidelines. The method development with predictable variations in the optimized method parameters is the most significant feature here. In the development phase of a method, robustness should be considered earlier-stated by ICH guideline.

Mobile phase composition, $\mathrm{pH}$, flow rate, temperature, wavelength are the parameters to find characteristic variations and the results are shown in table 6 and 7 for Atenolol and Nifedipine respectively.

Table 2: System suitability parameters for atenolol and nifedipine

\begin{tabular}{lll}
\hline Parameters & Atenolol & Nifedipine \\
\hline Linearity range $(\mu \mathrm{g} / \mathrm{ml})$ & $10-50 \mu \mathrm{g} / \mathrm{ml}-20 \mu \mathrm{g} / \mathrm{ml}$ \\
Regression equation & $\mathrm{y}=9454.2 \mathrm{x}-14348$ & $\mathrm{y}=32266 \mathrm{x}+31082$ \\
Slope & 9454.2 & 32266 \\
Intercept & 14348 & 31082 \\
Correlation coefficient & 0.9797 & 0.9679 \\
Retention Time (ret.) min & $2.79 \mathrm{~min}$ & $4.50 \mathrm{~min}$ \\
LOD $(\mu \mathrm{g} / \mathrm{ml})$ & 1.698 & 0.786 \\
LOQ $(\mu \mathrm{g} / \mathrm{ml})$ & 5.147 & 2.382 \\
Tailing factor & 1.073 & 1.323 \\
Theoretical plates & 4141.47 & 3967.10 \\
\hline
\end{tabular}

Table 3: Results for method precision intraday studies

\begin{tabular}{|c|c|c|c|c|c|c|c|}
\hline \multicolumn{8}{|c|}{ Precision-intraday } \\
\hline \multirow[t]{2}{*}{ Injection no } & \multicolumn{3}{|l|}{ Atenolol } & \multicolumn{4}{|l|}{ Nefidipine } \\
\hline & $10 \mu \mathrm{g}$ & $30 \mu \mathrm{g}$ & $50 \mu \mathrm{g}$ & Injection no & $4 \mu \mathrm{g}$ & $12 \mu \mathrm{g}$ & $20 \mu \mathrm{g}$ \\
\hline 1 & 103594 & 268106 & 478153 & 1 & 165874 & 481173 & 615869 \\
\hline 2 & 103545 & 267402 & 458241 & 2 & 165258 & 481654 & 614258 \\
\hline 3 & 103492 & 267105 & 475142 & 3 & 165159 & 484429 & 616369 \\
\hline 4 & 103684 & 264254 & 474157 & 4 & 165753 & 482554 & 617859 \\
\hline 5 & 103798 & 264456 & 468122 & 5 & 165456 & 482844 & 615741 \\
\hline 6 & 103882 & 263501 & 488153 & 6 & 165729 & 481433 & 615789 \\
\hline AVG & 103665.8 & 265343.6 & 473661.3 & AVG & 165538.2 & 482582.8 & 615980.8 \\
\hline STD DEV & 138.1454 & 1594.351 & 9138.676 & STD DEV & 265.947 & 1064.163 & 1060.909 \\
\hline$\%$ RSD & 0.13326 & 0.600863 & 1.929369 & $\%$ RSD & 0.160656 & 0.220514 & 0.172231 \\
\hline
\end{tabular}

Table 4: Results for method precision interday studies

\begin{tabular}{|c|c|c|c|c|c|c|c|}
\hline \multicolumn{8}{|c|}{ Precision-interday } \\
\hline \multirow[t]{2}{*}{ Injection no } & \multicolumn{3}{|l|}{ Atenolol } & \multicolumn{4}{|l|}{ Nifedipine } \\
\hline & $10 \mu \mathrm{g}$ & $30 \mu \mathrm{g}$ & $50 \mu \mathrm{g}$ & Injection no & $4 \mu \mathrm{g}$ & $12 \mu \mathrm{g}$ & $20 \mu \mathrm{g}$ \\
\hline 1 & 103594 & 268104 & 478153 & 1 & 165874 & 481173 & 615869 \\
\hline 2 & 102597 & 264146 & 488248 & 2 & 165788 & 481754 & 614278 \\
\hline 3 & 104562 & 267408 & 464854 & 3 & 167159 & 485229 & 616372 \\
\hline 4 & 105414 & 268809 & 475149 & 4 & 168153 & 483554 & 617259 \\
\hline 5 & 107453 & 258456 & 478654 & 5 & 167456 & 483864 & 615741 \\
\hline 6 & 103475 & 258714 & 488153 & 6 & 168929 & 481473 & 618789 \\
\hline AVG & 104515 & 264272.8 & 478868.5 & AVG & 167226.5 & 483174.8 & 616384.7 \\
\hline STD DEV & 1583.815 & 4278.55 & 8010.15 & STD DEV & 1133.775 & 1396.66 & 1394.25 \\
\hline$\%$ RSD & 1.515383 & 1.61899 & 1.67272 & $\%$ RSD & 0.677988 & 0.28905 & 0.22619 \\
\hline
\end{tabular}

\section{Forced degradation studies}

The stress studies were performed on Atenolol and Nifedipinedrug at $50 \mu \mathrm{g} / \mathrm{ml}$ concentration. unstressed sample(fig. 8) Here the bulk drug is subjected to acidic stress by adding $1.0 \mathrm{ml}$ of $0.1 \mathrm{M} \mathrm{HCl}$ (fig. 9) to drug solution and neutralized with $1.0 \mathrm{ml}$ of $0.1 \mathrm{M} \mathrm{NaOH}$, at $0 \mathrm{~min}, 30$ min, $1 \mathrm{~h}, 2 \mathrm{~h}, 4 \mathrm{~h}, 8 \mathrm{~h}, 6 \mathrm{~h}$ and $32 \mathrm{~h}$ respectively. Similarly, the basic stress studies were performed by adding $1.0 \mathrm{ml}$ of $0.1 \mathrm{M} \mathrm{NaOH}$ (fig. 10) and neutralized with $1 \mathrm{ml}$ of $0.1 \mathrm{M} \mathrm{HCl}$. Thermal studies were performed by heating the sample at $60^{\circ} \mathrm{C}$ (fig. 11) Oxidation studies were performed on the bulk drug by adding $2 \mathrm{ml}$ of $3 \% \mathrm{H}_{2} \mathrm{O}_{2}$, (fig. 12) and UV studies were also carried out by the sample at UV-Lamp $450 \mathrm{C}$ 
(fig. 13)respectively. All samples were placed in a different volumetric flask $(10 \mathrm{ml})$ and dissolved in HPLC grade methanol. Chromatographic system injected with final drug concentration for assay made with methanol. For all these stability study, the formation of degradable product was confirmed by comparing with the chromatogram of the solution kept under normal unstressed condition. All stressed samples were analysed by optimized UFLC method. The degradation data for Atenolol and Nifedipine was shown in below table 8.

Table 5: Recovery results for atenolol and nifedipine

\begin{tabular}{|c|c|c|c|c|c|c|}
\hline $\begin{array}{l}\text { Level of \% } \\
\text { recovery }\end{array}$ & $\begin{array}{l}\text { Amount of std drug } \\
\text { added }(\mu \mathrm{g} / \mathrm{ml})\end{array}$ & $\begin{array}{l}\text { Amount of } \\
\text { drug added }(\mu \mathrm{g} / \mathrm{ml})\end{array}$ & $\begin{array}{l}\text { Total amount of } \\
\text { drug }(\mu \mathrm{g} / \mathrm{ml})\end{array}$ & Difference & \% Recovery & Mean \\
\hline 50 & 20 & 10 & 30 & $\begin{array}{l}150652 \\
148151 \\
147884\end{array}$ & $\begin{array}{l}100.36 \\
98.69 \\
98.51\end{array}$ & 99.19 \\
\hline 100 & 20 & 20 & 40 & $\begin{array}{l}148341 \\
150541 \\
149780\end{array}$ & $\begin{array}{l}98.82 \\
100.28 \\
99.77\end{array}$ & 99.62 \\
\hline 150 & 20 & 30 & 50 & $\begin{array}{l}150047 \\
148442 \\
147391\end{array}$ & $\begin{array}{l}99.95 \\
98.88 \\
98.18\end{array}$ & 99.00 \\
\hline
\end{tabular}

Table 6: Results of robustness for atenolol

\begin{tabular}{|c|c|c|c|c|c|}
\hline \multicolumn{2}{|l|}{ Condition } & \multirow{2}{*}{$\begin{array}{l}\text { Tailing } \\
1.073\end{array}$} & \multirow{2}{*}{$\begin{array}{l}\text { \% RSD } \\
--\end{array}$} & \multirow{2}{*}{$\begin{array}{l}\text { Theoretical plates } \\
4158.49\end{array}$} & \multirow{2}{*}{$\begin{array}{l}\text { \%RSD } \\
--\end{array}$} \\
\hline As such condition (optimized & & & & & \\
\hline Mobile phase ratio & $70: 30$ & 1.059 & 0.66 & 4037.3 & 1.48 \\
\hline As such (75:25) & $85: 15$ & 1.179 & 0.28 & 4048.3 & 1.34 \\
\hline \multirow[t]{2}{*}{$\%$ of Ortho-phosphoric acid } & Decreased ( -0.2 units) & 1.847 & 1.29 & 4284.9 & 1.50 \\
\hline & Increased ( +0.2 units) & 0.98 & 1.87 & 4255.1 & 1.15 \\
\hline \multirow[t]{2}{*}{ Flow rate } & Decreased $(-0.2 \mathrm{ml} / \mathrm{min})$ & 1.020 & 0.89 & 4267.39 & 1.29 \\
\hline & Increased $(+0.2 \mathrm{ml} / \mathrm{min})$ & 1.099 & 1.20 & 4250.43 & 1.09 \\
\hline \multirow[t]{2}{*}{ Column temperature } & Decreased $\left(-5^{\circ} \mathrm{C}\right)$ & 1.267 & 1.32 & 4048.29 & 1.34 \\
\hline & Increased $\left(+5^{\circ} \mathrm{C}\right)$ & 1.183 & 0.83 & 4302.93 & 1.71 \\
\hline \multirow[t]{4}{*}{ Wave length } & Decreased $(1 \mathrm{~nm})$ & 0.545 & 1.37 & 4249.39 & 1.08 \\
\hline & Decreased (2 nm) & 1.288 & 1.60 & 4312.2 & 1.81 \\
\hline & Increased $(1 \mathrm{~nm})$ & 1.373 & 1.74 & 4313.22 & 1.83 \\
\hline & Increased (2 $\mathrm{nm})$ & 1.218 & 1.47 & 4292.08 & 1.58 \\
\hline
\end{tabular}

Table 7: Results of robustness for nifedipine

\begin{tabular}{|c|c|c|c|c|c|}
\hline \multicolumn{2}{|l|}{ Condition } & \multirow{2}{*}{$\begin{array}{l}\text { Tailing } \\
1.323\end{array}$} & \multirow[t]{2}{*}{ \%RSD } & \multirow{2}{*}{$\begin{array}{l}\text { Theoretical plates } \\
4358.49\end{array}$} & \multirow[t]{2}{*}{$\%$ RSD } \\
\hline As such condition (optimized & & & & & \\
\hline Mobile phase ratio & $70: 20$ & 0.959 & 0.141 & 3732.39 & 1.47 \\
\hline As such $(75: 25)$ & $85: 15$ & 1.865 & 1.19 & 3348.30 & 1.28 \\
\hline \multirow[t]{2}{*}{$\%$ of Ortho-phosphoric acid } & Decreased ( -0.2 units) & 1.846 & 0.84 & 4946.9 & 1.51 \\
\hline & Increased (+0.2 units) & 1.298 & 1.16 & 3456.74 & 1.42 \\
\hline \multirow[t]{2}{*}{ Flow rate } & Decreased $(-0.2 \mathrm{ml} / \mathrm{min})$ & 1.170 & 1.93 & 4861.39 & 1.84 \\
\hline & Increased (+0.2 $\mathrm{ml} / \mathrm{min})$ & 1.249 & 0.97 & 4285.43 & 0.81 \\
\hline \multirow{2}{*}{ Column temperature } & Decreased $\left(-5^{\circ} \mathrm{C}\right)$ & 1.167 & 0.82 & 4948.29 & 1.59 \\
\hline & Increased $\left(+5^{\circ} \mathrm{C}\right)$ & 1.583 & 1.22 & 4202.93 & 1.82 \\
\hline \multirow[t]{4}{*}{ Wave length } & Decreased (1 nm) & 0.835 & 1.22 & 4839.39 & 1.39 \\
\hline & Decreased (2 nm) & 1.18 & 1.34 & 3893.92 & 1.92 \\
\hline & Increased $(1 \mathrm{~nm})$ & 1.448 & 0.46 & 4839.22 & 1.58 \\
\hline & Increased (2 nm) & 1.78 & 1.93 & 3772.08 & 1.59 \\
\hline
\end{tabular}

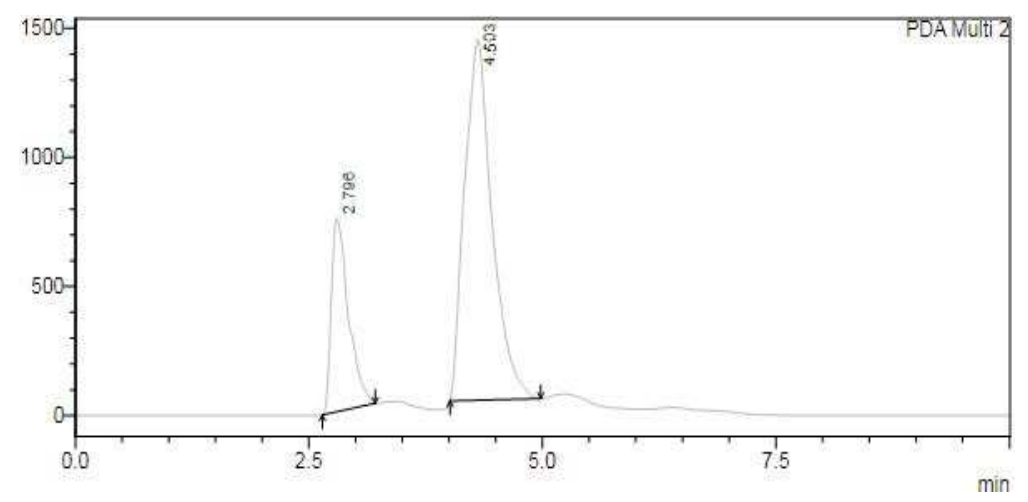

Fig. 8: Chromatogram of unstressed sample 


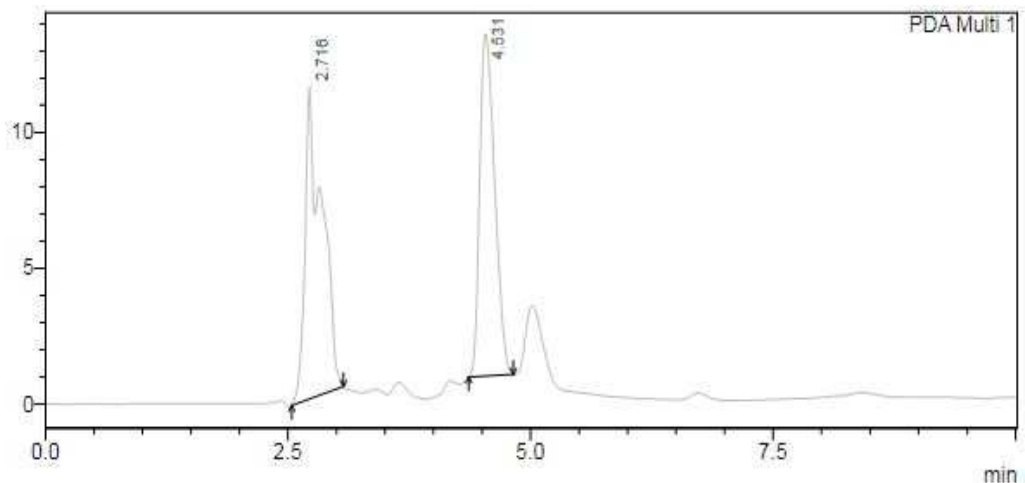

Fig. 9: Chromatogram of acid hydrolysis

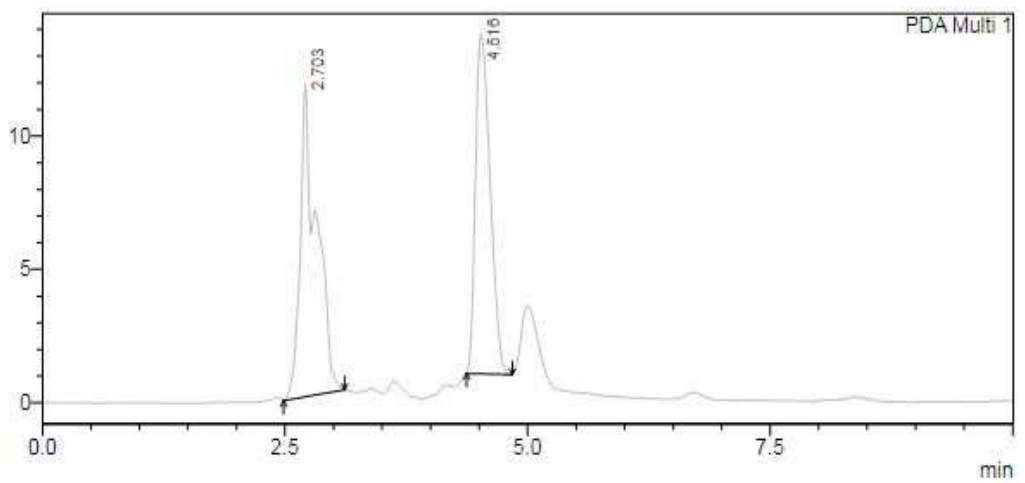

Fig. 10: Chromatogram of base hydrolysis

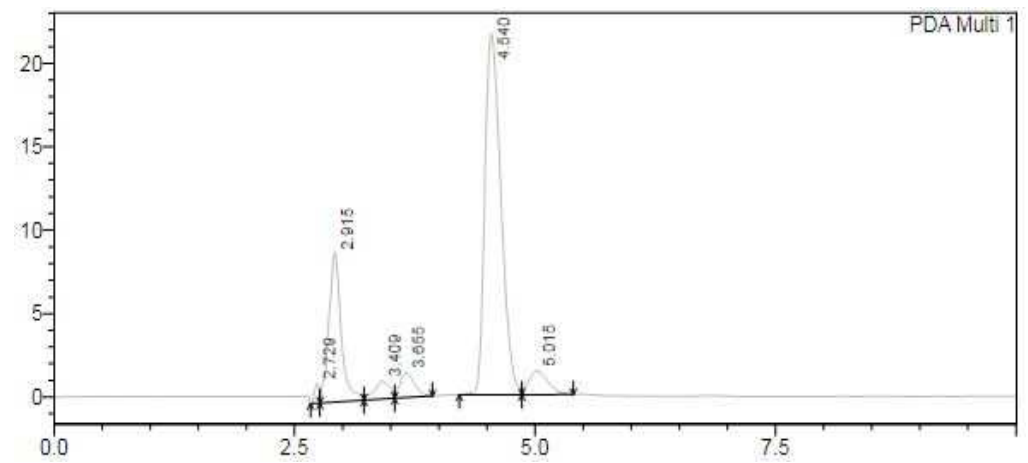

Fig. 11: Chromatogram of thermal stress

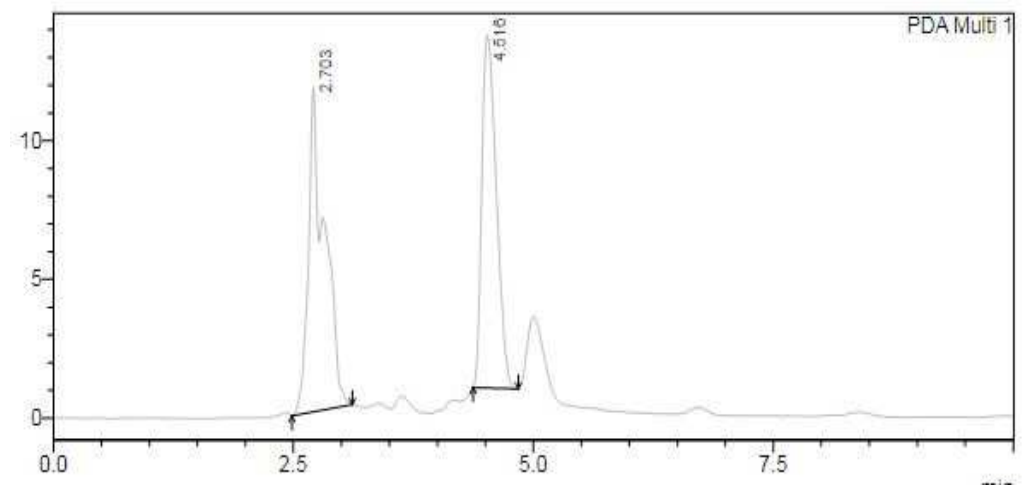

Fig. 12: Chromatogram of peroxide stress 


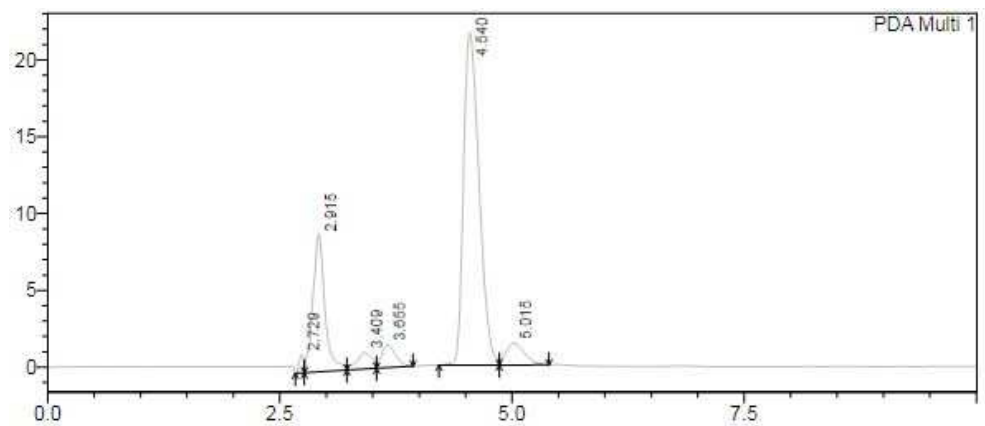

Fig. 13: Chromatogram of UV stress

Table 8: Results for recovery studies of atenolol and nifedipine after the stress conditions (\% recovery of drug)

\begin{tabular}{|c|c|c|c|c|c|c|}
\hline Time & Drug & UV & Thermal & $0.1 \mathrm{~N} H C L$ & $0.1 \mathrm{~N} \mathrm{NaoH}$ & $3 \% \mathrm{H}_{2} \mathrm{O}_{2}$ \\
\hline \multirow[t]{2}{*}{0 Min } & Atenolol & $82.24 \%$ & $73.11 \%$ & $71.65 \%$ & $72.34 \%$ & $56.47 \%$ \\
\hline & Nifedipine & $84.23 \%$ & $76.76 \%$ & $87.79 \%$ & $89.35 \%$ & $81.34 \%$ \\
\hline \multirow[t]{2}{*}{$30 \mathrm{Min}$} & Atenolol & $77.34 \%$ & $60.76 \%$ & $57.29 \%$ & $61.34 \%$ & $44.19 \%$ \\
\hline & Nifedipine & $80.34 \%$ & $67.31 \%$ & $84.14 \%$ & $87.34 \%$ & $74.34 \%$ \\
\hline \multirow[t]{2}{*}{$1 \mathrm{~h}$} & Atenolol & $69.32 \%$ & $47.86 \%$ & $52.3 \%$ & $54.34 \%$ & $32.47 \%$ \\
\hline & Nifedipine & $72.43 \%$ & $50.16 \%$ & $78.86 \%$ & $80.34 \%$ & $68.23 \%$ \\
\hline \multirow[t]{2}{*}{$2 \mathrm{~h}$} & Atenolol & $61.73 \%$ & $28.66 \%$ & $37.47 \%$ & $42.34 \%$ & $25.19 \%$ \\
\hline & Nifedipine & $67.34 \%$ & $37.14 \%$ & $74.78 \%$ & $78.38 \%$ & $60.87 \%$ \\
\hline \multirow[t]{2}{*}{$4 \mathrm{~h}$} & Atenolol & $54.22 \%$ & $19.81 \%$ & $28.07 \%$ & $30.87 \%$ & $15.47 \%$ \\
\hline & Nifedipine & $59.34 \%$ & $21.69 \%$ & $67.27 \%$ & $70.34 \%$ & $44.34 \%$ \\
\hline \multirow[t]{2}{*}{$8 \mathrm{~h}$} & Atenolol & $47.82 \%$ & $8.89 \%$ & $14.64 \%$ & $13.32 \%$ & $4.43 \%$ \\
\hline & Nifedipine & $52.23 \%$ & $30.15 \%$ & $59.65 \%$ & $57.23 \%$ & $32.62 \%$ \\
\hline \multirow[t]{2}{*}{$16 \mathrm{~h}$} & Atenolol & $39.22 \%$ & --- & $6.34 \%$ & --- & --- \\
\hline & Nifedipine & $43.87 \%$ & --- & 44.64 & $43.24 \%$ & $22.23 \%$ \\
\hline \multirow[t]{2}{*}{$32 \mathrm{~h}$} & Atenolol & $22.43 \%$ & $---\%$ & --- & --- & --- \\
\hline & Nifedipine & $---44.24 \%$ & --- & -- & --- & -- \\
\hline
\end{tabular}

\section{CONCLUSION}

A simple, quick, sensitive, reliable, and precise stability indicating UFLC method was developed and validated for the estimation of Atenolol and Nifedipine. The method was observed to be linear, accurate, precise, and turned out to be sensitive, convenient and successful with good resolution for the estimation of Atenolol and Nifedipine in both bulk and pharmaceutical dosage forms in industries and research labs for routine sample analysis.

\section{ACKNOWLEDGEMENT}

The authors express their sincere thanks to the Principal, JSS College of Pharmacy, Mysuru and JSS Academy of Higher Education and Research, Mysuru for providing the necessary facilities to carry out the research work.

\section{AUTHORS CONTRIBUTIONS}

All the author have contributed equally.

\section{CONFLICT OF INTERESTS}

Declared none

\section{REFERENCES}

1. British Pharmacopoeia, Her Majesty's Stationary Office, London, UK, Br. Pharmacopoeia, Her Majesty's Station. Off. London, UK; 2013.
2. Freemantle N, Cleland J, Young P, Mason J, Harrison J. $\beta$ blockade after myocardial infarction: a systematic review and Meta-regression analysis. Br Med J 1999;26:1730-7.

3. Anandakumar K, Jayamariappan M. Absorption correction method for the simultaneous estimation of amlodipine besylate, valsartan and hydrochlorothiazide in bulk and in combined tablet dosage form. Int J Pharm Sci Res 2011; 3:23-7.

4. Shaalan RA, Belal TS. Simultaneous spectrofluorometric determination of amlodipine besylate and valsartan in their combined tablets. Drug Testing Anal 2010 1;2:48993.

5. Jeffery GH, Bassette J, Mendham J, Denney RC. In: Vogel's Textbook of Quantitative Chemical Analysis, Longman $5^{\text {th }}$ Edition Publication; 1998. p. 668.

6. Chatwal G, Anand KS. Hi Himalaya Publishing House; 2015. p. 1.1-1.24, 2.566-2.586, 2.624-2.639.

7. An Introduction To Analytical Method Development For Pharmaceutical Formulations Pharmainfo_net. Available from: Htm: www. $\backslash$ AnalyticalMethodDevelopmentandValidation. [Last accessed on 20 Dec 2017].

8. www. \ReversePhaseHPLCBasicsforLC-MS-IMP. [Last accessed on 20 Dec 2017].

9. Indian Pharmacopoeia. Vol. I. The Controller of Publication, New Delhi; 1996. 